\title{
Morfologia das células do sangue periférico em emas (Rhea americana)
}

Eunice Anita de Moura FORTES ${ }^{1}$

Antônio Francisco de SOUSA ${ }^{2}$

Ezequiel Cardozo Saraiva de ALMEIDA $^{3}$

Aírton Mendes CONDE JÚNIOR ${ }^{1}$

Weber Leal de MOURA ${ }^{1}$

\section{Correspondência para:}

EuniceAnita deMouraFortes, Departamento de Morfologia, Centro de Ciências da Saúde, Universidade Federal do Piauí, Campus Universitário Ministro Petrônio Portella, 64049-550, Teresina - PI, euniceamf@ufpi.br

Recebido para publicação: 19/09/2007 Aprovado para publicação: 30/04/2009

\author{
1 - Departamento de Morfologia do Centro de Ciências da Saúde da Universidade \\ Federal do Piauí, Teresina-PI \\ 2 - Departamento de Clínica e Cirurgia Veterinária do Centro de Ciências Agrárias \\ da Universidade Federal do Piauí, Teresina-PI \\ 3 - Mestrando em Ciência Animal do Centro de Ciências Agrárias da Universidade \\ Federal do Piauí, Teresina- PI
}

\section{Resumo}

A ema (Rhea americana) é uma ave sul-americana do grupo das ratitas, da ordem Rheiforme, freqüentemente explorada com fins econômicos, como pecuária alternativa em países europeus e sul-americanos. No Brasil, destaca-se o Rio Grande do Sul e, em fase inicial, o Nordeste. O presente estudo objetivou descrever a morfologia das células sangüíneas em ema. Neste trabalho foram utilizados dez exemplares, desconsiderando-se idade e sexo. Foram colhidos $3 \mathrm{~mL}$ de sangue periférico por punção da veia braquial, com seringa descartável. As amostras foram utilizadas, em parte, na confecção de extensões coradas com Leishman. Feita a análise morfológica ao Microscópio de Luz, foram observados sete tipos celulares nucleados. O eritrócito mostrouse elíptico, com núcleo geralmente condensado, de forma elíptica; citoplasma acidófilo. O trombócito apresentou-se elíptico, com núcleo localizado em um dos pólos; citoplasma pálido. Quanto aos leucócitos, de forma arredondada, entre os granulócitos os heterófilos apresentaram-se com núcleo excêntrico, condensado, lobulado; citoplasma rico em grânulos fusiformes de coloração salmão. Os eosinófilos distinguem-se dos heterófilos pelos grânulos arredondados eosinofílicos. Os basófilos destacam-se dos outros granulócitos pelo núcleo grande e central, com grânulos citoplasmáticos específicos arredondados e fortemente basofílicos. Entre os agranulócitos, os monócitos mostraram núcleo rineforme, freqüentemente central, de cromatina frouxa, com pequenas áreas de condensação; citoplasma levemente basofílico e com vacúolos. Os linfócitos apresentaram-se variados em forma e tamanho; núcleo grande com cromatina frouxa, com alguns nucléolos; citoplasma escasso e basofílico. As células do sangue periférico de Rhea americana apresentam ao Microscópio de Luz morfologia semelhante às demais aves já estudadas.

\section{Introdução}

A ema, maior ave nativa, encontra-se entre os componentes da fauna silvestre que apresentam elevado potencial econômico, despertando assim, o interesse dos criadores. Pertencente à ordem Rheiforme, família Rheidae e ao gênero Rhea; faz parte do grupo das aves ratitas, juntamente com a avestruz da África e o Emu da Austrália. ${ }^{1}$
A colheita do sangue periférico de aves pode ser feita por meio do corte de unhas ${ }^{2,3,4,5}$ de punção das veias ulnar ${ }^{2,3,5,6}$, braquial $^{6,7,8}$, metatársica medial ${ }^{2,5,7}$ e jugular $2,3,4,5,6,7$. As amostras de sangue que podem ser colhidas em emas variam de grandes volumes em animais adultos ao limite de $2 \mathrm{ml}$ nos filhotes ${ }^{2}$. Pode ser colhida com segurança a quantidade correspondente a $1 \%$ do peso corporal de uma ave 
normal. ${ }^{4,5} \mathrm{Na}$ maioria das ratitas ${ }^{9}$ o sangue é coletado da veia ulnar cutânea, localizada na superfície ventral da asa. Em pequenas ratitas e pintos de avestruz, a veia metatarsal medial é freqüentemente a mais usada. A colheita do sangue é facilitada com o uso de agulha 21.

Geralmente, o sangue nas aves apresenta as seguintes células: glóbulos vermelhos (eritrócitos); glóbulos brancos (granulócitos: heterófilos, eosinófilos e basófilos; agranulócitos: linfócitos e monócitos) e trombócitos. ${ }^{4,8,10,11}$ A morfologia das células sangüíneas em ratitas foi descrita de um modo geral, e especificamente em avestruz.?

Os eritrócitos são células nucleadas de forma oval, com núcleo ovalado ${ }^{10,11}$; com tamanho que varia entre 11 e $16 \mathrm{~mm}$ de comprimento e de 6 a $10 \mathrm{~mm}$ de largura, sendo as Rheiformes possuidoras das maiores células da classe das aves ${ }^{11}$. Em ratitas $^{9}$ têm a forma oval com núcleo também oval, centralmente localizado, com cromatina condensada. No avestruz, o núcleo varia de tamanho e forma, de oval alongado a forma de lágrima; citoplasma de coloração rosa-alaranjada uniforme quando corado com Wright ${ }^{9}$. Os neutrófilos são representados pelos heterófilos, os quais apresentam o citoplasma repleto de grânulos acidófilos. ${ }^{2,10} \mathrm{O}$ heterófilo maduro de ratitas é redondo, com núcleo segmentado, muitas vezes ocluído por numerosos grânulos fusiformes de cor laranja e citoplasma claro. ${ }^{9}$ Os eosinófilos apresentam também grânulos citoplasmáticos acidófilos, com forma diferente dos grânulos dos heterófilos. ${ }^{11}$ Em ratitas geralmente tem núcleo bilobulado, citoplasma azul claro9 com abundantes grânulos vermelhos para rosa, pequenos e redondos. Os basófilos possuem grânulos citoplasmáticos basofílicos. ${ }^{11} \mathrm{O}$ de ratitas tem núcleo excêntrico, com forma redonda a oval, não segmentado; citoplasma em quantidade moderada, de cor púrpura, com grânulos escuros metacromáticos. ${ }^{9}$ Os linfócitos podem se apresentar nos tamanhos grande e pequeno; têm um único núcleo, sem divisões. ${ }^{11}$ Em ratitas é similar ao das outras espécies de aves, com células variando em tamanho, de pequenos a médios e grandes linfócitos; núcleo de forma redonda e citoplasma variando em quantidade, de escasso a moderado, e geralmente basofílico. ${ }^{9}$ Os monócitos, geralmente maiores que os linfócitos, podem apresentar o núcleo redondo, bilobulado ou em forma de feijão. ${ }^{11}$ Aqueles de ratitas tem morfologia similar aos monócitos de mamíferos. É grande, com moderada quantidade de citoplasma azul acinzentado, que ocasionalmente contém vacúolos pequenos e discretos; seu núcleo é pleomórfico, com cromatina menos condensada que nos linfócitos. ' Ao contrário dos mamíferos, as aves têm trombócitos em vez de plaquetas. ${ }^{12}$ São células com forma redonda a oval; núcleo redondo; citoplasma claro e reticulado. ${ }^{9}$

O presente trabalho objetivou descrever a morfologia das células sangüíneas na ema. A realização desta pesquisa com a ema (Rhea americana), devese aos fatos: de ser facilmente encontrado no Estado do Piauí, principalmente nos cerrados do sul; de que não há na literatura levantada não foram encontrados trabalhos sobre o assunto, e ainda por serem considerados estes conhecimentos básicos, necessários para a realização de outros estudos com a espécie.

\section{Material e Método}

Neste estudo, foram utilizados 10 exemplares hígidos de Rhea americana, popularmente conhecida como ema, machos e fêmeas adultos, provenientes do Município de Teresina, PI. A apreensão e contenção dos animais foram feitas por meios físicos pelos tratadores da própria fazenda, com cuidados especiais para não asfixiar os animais contidos. Realizou-se o encapuzamento para facilitar a contenção e a realização das manobras. Para a realização das análises morfológicas, foram colhidos $2 \mathrm{~mL}$ de sangue periférico de cada animal por punção da veia braquial, utilizando-se 
seringa descartável com capacidade para $5 \mathrm{~mL}$, provida de agulha $25 \times 7$. As amostras foram colocadas em tubos de ensaio com tampa de borracha contendo anticoagulante EDTA (ácido etileno diamino tetracético) em solução a 10\%, fazendo-se a transferência imediata de uma gota de sangue da seringa para lâmina de vidro, que foi fixada e levada ao laboratório. Posteriormente, foram feitas três extensões de sangue que foram fixadas e juntamente com a anterior submetidas à coloração para a análise morfológica. As extensões foram coradas pelo método de Leishman, sendo as lâminas examinadas ao microscópio de luz em aumento de 1.000x. As fotomicrografias das lâminas foram realizadas por meio de sistema fotomicrográfico (Olympus - BX41).

\section{Resultados}

$\mathrm{Na}$ análise microscópica de extensões do sangue periférico corado observaram- se as seguintes células: trombócito, eritrócito, heterófilo, eosinófilo e basófilo; linfócito e monócito. Em relação à linhagem trombocítica, foi possível observar células de forma elíptica com citoplasma escasso e hialino, restrito aos pólos da célula; núcleo elíptico, fortemente basofílico, ocupando quase que totalmente a célula, com chanfraduras (Figura 1a). Foram observados eritrócitos de forma elíptica, apresentando núcleo também elíptico, com cromatina condensada; citoplasma abundante e acidófilo (Figura 1a). O heterófilo maduro mostrou-se de forma arredondada com alta relação citoplasma/núcleo. O núcleo é lobulado, de cromatina condensada, com localização excêntrica ou periférica. Apresenta grânulos citoplasmáticos de formas alongadas variadas (fusiformes, até com forma de baqueta), de coloração salmão mais ou menos intensa (Figura 1b). O eosinófilo maduro apresentou-se esférico, com o citoplasma repleto de grânulos uniformes, arredondados e; núcleo

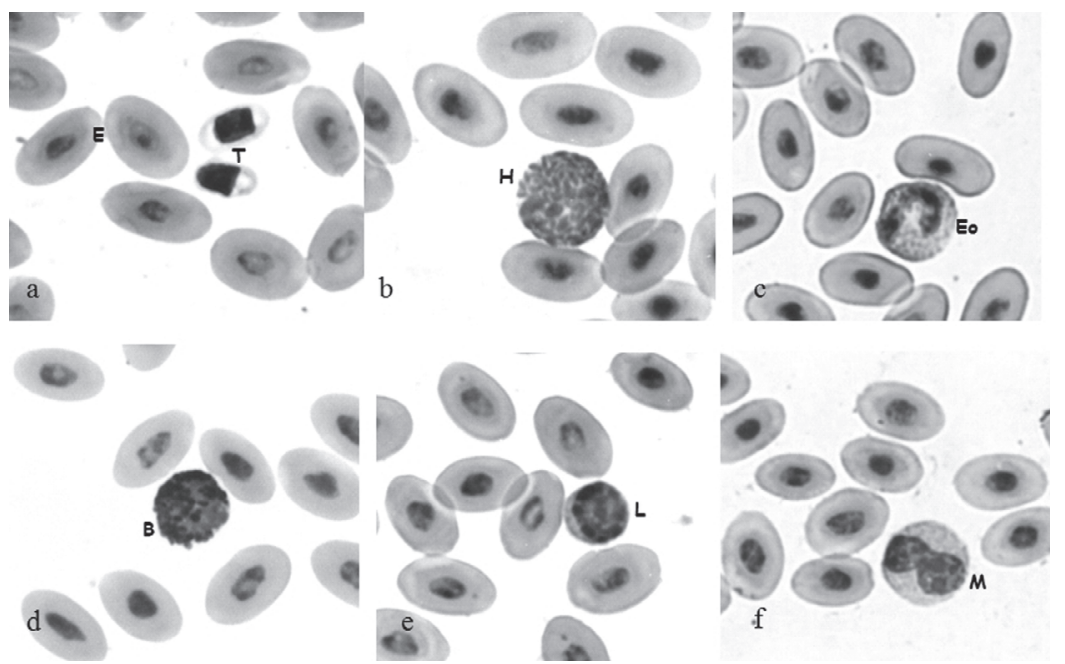

Figura 1 - Fotomicrografias de extensão de sangue de Rhea americana. Em a), observam-se dois trombócitos (T), com núcleo grande, citoplasma escasso e restrito aos pólos da célula. Encontram-se em meio a vários eritrócitos maduros (E) de forma elíptica, citoplasma abundante acidófilo e núcleo com cromatina condensada. Em b), identifica-se um heterófilo (H), com núcleo lobulado, cromatina condensada; grânulos citoplasmáticos alongados e acidófilos. Em c), notar um eosinófilo (Eo) com núcleo periférico, mostrando três lóbulos ligados por pontes de cromatina; citoplasma com grânulos arredondados e acidófilos. Em d), destaca-se um basófilo (B) com grânulos específicos intensamente basofílicos e de forma arredondada, no citoplasma. Observa-se núcleo grande, condensado e central. Em e), identificase um linfócito $(\mathbf{L})$ com núcleo grande, arredondado, com pequenas áreas de cromatina condensada, citoplasma escasso e basofílico. Em f), destaca-se um monócito maduro (M). Nota-se um núcleo, com cromatina frouxa e pequenas áreas condensadas, citoplasma basofílico com vacúolos. As células em destaque encontram-se envoltas por vários eritrócitos maduros (E). Método de Leishman. Aumento de $1000 x$ 
periférico, lobulado, com presença de cromatina condensada (Figura 1c). O basófilo maduro apresentou forma esférica, menor quando comparado aos demais granulócitos; núcleo central, esférico e grande, ocupando quase toda a célula, com áreas de cromatina condensada; citoplasma escasso, com poucos grânulos citoplasmáticos específicos fortemente corados, de forma esférica (Figura 1d).

A análise morfológica de extensões de sangue revelou a presença de células com características da linhagem linfocítica de forma arredondada, de núcleo grande também arredondado, com cromatina frouxa, e pequenas áreas de cromatina condensada; citoplasma escasso e basofílico (Figura 1e).

$\mathrm{Na}$ linhagem monocítica, a célula apresentou-se volumosa, arredondada, com citoplasma levemente basófilo, rico em grandes vacúolos; núcleo rineforme, cromatina frouxa, com pequenas áreas de cromatina condensada (Figura 1f).

\section{Discussão}

Entre os meios de contenção das aves rheiformes preconizados como adequados ${ }^{2}$, elegeu-se conter os animais fisicamente ${ }^{7,13}$, obtendo-se bons resultados. Preferiu-se realizar a colheita de sangue por punção da veia braquial ${ }^{4,6,7,8}$, pela facilidade de acesso, por estar em uma área desprovida de penas e por ser um local não visível aos outros animais. Tomou-se o cuidado de evitar o colabamento da veia, muito comum em $a^{2} s^{5}$, o que poderia levar à formação de hematoma ${ }^{2}$, para tanto a aspiração do sangue foi realizada de forma lenta e com compressão local após a retirada da agulha ${ }^{2}$. Colheu-se $2 \mathrm{~mL}$ de sangue, limite aceitável mesmo para um recém-nascido ${ }^{6}$, por ser considerada uma quantidade suficiente para a realização de todas as análises morfológicas.

Em relação aos tipos celulares encontrados nas aves, apesar de pertencerem a outra Classe de animais, apresentam as mesmas células observadas nos demais vertebrados, entretanto, todas as células são nucleadas. ${ }^{2,8,9,10,11,14}$ Observou-se os sete diferentes tipos de células no sangue periférico de emas.

A forma exclusivamente eliptica dos trombócítos na Rhea americana, representa a diferença significante entre estas aves e as outras que segundo estudos, além da forma elíptica, foram observados trombócitos nas formas esférica e oval. ${ }^{8,9,11,14}$ Os trombócitos das aves em geral ${ }^{10}$ mostram-se como células nucleadas, menores que os eritrócitos, com núcleo central e alongado contendo massas densas de heterocromatina; citoplasma basofílico e finamente reticulado podendo apresentar numerosos grânulos específicos azurófilos. Certos autores chamaram erroneamente os trombócitos de plaquetas ${ }^{14}$ descrevendo as maduras como células ovais a redondas, pequenas, com núcleo central, roxo-escuro com cromatina agrupada e densa; citoplasma azul-claro a pálido reticulado ou não, homogêneo com grânulos vermelhos finos. Outros trabalhos relatam apenas ${ }^{11}$ que os trombócitos têm a forma oval e são nucleados. Em $B$ uteo ${ }^{8}$, os trombócitos são predominantemente elípticos, com núcleo basófilo ocupando grande parte do citoplasma, com cromatina condensada grosseiramente e grumosa, citoplasma hialino vacuolisado em um dos pólos das células. Dois grânulos azurófilos são visíveis em um dos pólos de quase todos os trombócitos. Podem também ser observados nas formas esférica e oval.

O eritrócito das aves é semelhante aos dos peixes e anfíbios. Tem a forma oval e um núcleo também oval; o citoplasma varia de laranja-rosado a vermelho nas colorações de rotina. ${ }^{10}$ Os eritrócitos dos avestruzes ${ }^{7}$ são nucleados, assim como os de todos os vertebrados não mamíferos (peixes, anfíbios, répteis e aves). Quanto às características das células sangüíneas aviárias ${ }^{14}$ coradas pelo método de Wright, os eritrócitos são células elípticas, com núcleo oval, central e roxoescuro com cromatina uniformemente agrupada e citoplasma rosa-alaranjado uniforme. Os eritrócitos das aves rheiformes ${ }^{11}$ são os maiores das aves. Os eritrócitos maduros ${ }^{8}$ de Buteo magnirostris são 
elípticos de núcleo também elíptico, basofílico e central, com cromatina uniformemente condensada em grumos, e citoplasma acidófilo. Neste trabalho, apresentaram-se nucleados, concordando totalmente com vários autores. ${ }^{7,8,14} \mathrm{O}$ eritrócito apresentou-se de forma elíptica e núcleo também elíptico, com cromatina condensada; citoplasma abundante e acidófilo, como em $B$ uteo ${ }^{8}$ e em discordância com outros autores ${ }^{9,10,11}$ que encontraram células ovais com núcleos também ovais.

O heterófilo nas aves ${ }^{15}$ é arredondado, podendo sua forma ser distorcida pela distribuição polar dos grânulos específicos ou pela lobulação; o núcleo é mais basófílo do que o do eosinófilo, podendo apresentar dois ou três lóbulos. Tal como nos répteis, os grânulos citoplasmáticos são acidófilos em heterófilos e eosinófilos. São leucócitos maiores que os eosinófilos. A célula geralmente tem uma forma arredondada, de núcleo multilobulado com massas condensadas de heterocromatina. No citoplasma há grânulos em forma de bastões ou fusiforme, eosinófílos e brilhantes. ${ }^{10}$ Em gavião carijó ${ }^{8}$ são esféricos, com núcleo periférico contendo três a quatro lóbulos; o citoplasma é pouco corado com grânulos acidófilos volumosos de aspecto abaulado com extremidades delgadas, podendo ter grânulos pequenos esféricos e em bastão com discreta basofilia. Em Rhea americana, observou-se o heterófilo maduro de forma arredondada com relação citoplasma/núcleo elevada, núcleo lobulado de cromatina condensada, com localização excêntrica ou periférica; grânulos citoplasmáticos de formas alongadas variadas (fusiformes, em baqueta), de coloração salmão mais ou menos intensa, concordando com descrições anteriores. . $^{8,110,14,15}$ Não foram observados grânulos esféricos ${ }^{8}$, conforme outro autor.

$\mathrm{O}$ eosinófilo de aves ${ }^{10}$ tem núcleo multilobulado, com heterocromatina grosseiramente granulada, com citoplasma azul muito claro, geralmente obscurecido pelos grânulos citoplasmáticos, que são mais refringentes que os do heterófilo. Pode ser redondo ${ }^{14}$, contendo um núcleo roxo-claro bilobulado com cromatina agrupada e citoplasma azul-pálido com grânulos de vermelho a laranja, redondos. Em Buteo ${ }^{8}$, são esféricos, com núcleo apresentando dois a três lóbulos volumosos com cromatina em grumos; por todo o citoplasma encontramse grânulos eosinofílicos esféricos pequenos e escuros distribuídos de forma agrupada ou às vezes sobre o núcleo. Neste trabalho o eosinófilo maduro de Rhea americana, apresentou-se esférico, com o citoplasma repleto de grânulos uniformes, arredondados e eosinofilicos, com núcleo periférico, lobulado e com presença de cromatina condensada, em concordância com outros autores. $7,8,1,10,11,14$

O basófilo das aves é semelhante ao dos mamíferos..$^{10}$ Pode apresentar-se como uma célula de forma redonda ${ }^{16}$, com núcleo individual, não lobulado, citoplasma com grânulos fortemente corados em púrpura, alguns dos quais sobre o núcleo. As vezes são redondos de tamanho pequeno a médio ${ }^{14}$, com um núcleo azul-claro, central, redondo a oval, com citoplasma preenchido por grânulos intensamente basofílicos ${ }^{11}$ que freqüentemente obscurecem o núcleo. Mostram-se também como células esféricas ${ }^{8}$, com núcleo volumoso e irregular, contendo cromatina frouxa e nucléolo visível; numerosos grânulos fortemente basofílicos são encontrados no citoplasma, dispostos em cordões na periferia da célula ou de forma isolada sobre o núcleo, ou ainda poucos grânulos distribuídos apenas na periferia da célula. O basófilo de Rhea americana mostrou forma esférica, menor quando comparado aos demais granulócitos; núcleo central, esférico e grande ocupando quase toda a célula, com áreas de cromatina condensada; citoplasma escasso, com poucos grânulos citoplasmáticos específicos fortemente basofílicos, de forma esférica, concordando com vários autores. ${ }^{8,9,10,11,14,17}$

Para aves em geral ${ }^{10}$ foram descritos linfócitos nos tamanhos pequeno, médio e grande de forma predominantemente redonda com contorno regular; o núcleo é centralmente localizado, podendo ser polarizado em algumas células; núcleo com 
massas densas de heterocromatina características; a proporção núcleo/citoplasma é elevada; o citoplasma apresenta aspectos variáveis, podendo ser homogêneo e se corar fracamente, ou intensamente floculado (fina e levemente reticulado, ou densa e grosseiramente reticulado) com material basofílico; pode apresentar grânulos de coloração magenta. Para outros autores ${ }^{14}$, os linfócitos são células redondas de tamanhos variados, com núcleo roxo-escuro, redondo a ligeiramente denteado, centralmente localizado, com uma cromatina reticulada ou densamente agrupada; o citoplasma é basofílico e homogêneo. Em Buteo os linfócitos são esféricos, com variação de tamanho, predominando os médios, com núcleo geralmente esférico sendo às vezes indentado, com cromatina condensada em grumos; o citoplasma é escasso e basofílico com grânulos azurófilos nas proximidades do núcleo. São também encontrados linfócitos pequenos com núcleo extremamente condensado e linfócitos grandes com núcleo e cromatina frouxa.

A análise morfológica de extensões de sangue de Rhea americana mostrou células com características da linhagem linfocítica apresentando-se de forma arredondada, de núcleo grande também arredondado, com cromatina frouxa, e pequenas áreas de cromatina condensada e citoplasma escasso e basofílico, concordando com vários autores. $8,9,10,11,14$

Nas aves em geral ${ }^{10} \mathrm{o}$ monócito é uma célula grande, pois geralmente o diâmetro do seu núcleo se aproxima do diâmetro médio do linfócito; a relação núcleo/citoplasma é menor que no linfócito; a célula é de forma geralmente esférica, sendo outras numerosas configurações também observadas; seu núcleo é rineforme ou em forma de feijão com heterocromatina reticulada fina; na porção justanuclear podem ser observados grânulos laranjas ou matizados. Em outros $\operatorname{casos}^{14}$, são células grandes redondas e irregularmente formadas, com núcleo roxo, oval ou bilobado e excêntrico com cromatina delicada; o citoplasma é cinza-azulado e finamente granular. Em Buteo ${ }^{8}$ são esféricos, extremamente volumosos, têm um núcleo em forma de rim com cromatina frouxa e presença de nucléolos; citoplasma mais intensamente basofílico na periferia da célula, contendo finos grânulos azurófilos em toda sua extensão; vacúolos citoplasmáticos são observados com freqüência. A célula de Rhea americana apresentou-se volumosa, arredondada, de citoplasma levemente basófilo, rico em grandes vacúolos, contendo núcleo rineforme de cromatina frouxa, com pequenas áreas de condensação. Não foram notados monócitos com núcleo redondo ou bilobulado ${ }^{11}$ de forma mais próxima ao grão de feijão.

\section{Conclusões}

No sangue de Rhea americana são observados os mesmos tipos celulares morfologicamente semelhantes aos encontrados em outras aves e sem variação em relação ao sexo. A forma unicamente elíptica do trombócito na ema sugere estudos hematológicos em outras aves silvestres para elucidar se esta exclusividade morfológica é restrita a esta espécie.

\section{Morphology of cells peripheral blood in rheas (Rhea americana)}

\section{Abstract}

The rhea (Rhea americana) is a South American bird of the ratite group and of the Rheiformes order. It has been exploited for economical purposes, as cattle alternative in European and South American countries. In Brazil, the State of Rio Grande do Sul is outstanding, in rhea rearing and it is in the process of implantation in the Country Northeasty Region. This work aims to describe the morphology of the blood cells in rheas. In this work ten rheas were used, regardless
Key words: Rhea americana. Ema. Blood. Leukocytes. Erythrocytes. Thrombocytes. 
age and sex. Two $\mathrm{ml}$ of peripheral blood were collected by puncture of the brachial vein with disposable syringe. The samples here partially used to make extensions with Leishman stain. Seven types of nucleate cells have been observed through morphologic analysis on the light microscope. The erythrocyte revealed an elliptical form, with condensed nucleus of elliptical form; acidophilic cytoplasm. The thrombocyte revealed an elliptical form, with nucleus located in one of the polar regions; pale cytoplasm. As to the round-shaped leukocytes, within the granulocytes, the heterophils presented excentric, condensed, and lobulated nucleus; cytoplasm rich in fusiform salmon-colored granules. The eosinophils distinguish from the heterophils due to the round eosinophilic granules. The basophils stand out from the other granulocytes due to its large and central nucleus with round specific cytoplasmic and highly basophilic granules. Within the agranulocytes, the monocytes presented reniform nucleus, which is frequently central, with slack chromatin, with small areas of condensation; cytoplasm lightly basophilic and with vacuoles. The lymphocytes presented varies forms and sizes; large nucleus with slack chromatin with some nucleoli; scarce and basophilic cytoplasm. The cells of the peripheral blood of Rhea americana present on the light microscope morphology similar to the other birds which have already been studied.

\section{Referências}

1 GIANNONI, M. L. Emas \& avestruzes: uma alternativa para o produtor rural. Jabuticabal: FUNEP, 1996.

2 GARCIA-NAVARRO, C. E. K.; PACHALY, J. R. Manual de hematologia veterinária. São Paulo: Varela, 1994. cap. 13, p. 135-142.

3 DYCE, K. M.; SACK, W. O.; WENSING, C. J. G. Anatomia das aves. In: Tratado de anatomia veterinária. 2. ed. Rio de Janeiro: Guanabara Koogan, 1997. cap. 39, p. 631-650.

4 FUDGE, A. M. Clinical hematology and chemistry of ratites. In: TULLY, T. N.; SHANE, S. M. Ratite management, medicine, and surgery. Krieger, Malabar: Flórida, 1996. cap. 11, p. 105-114.

5 OGLESBEE, B. L. Técnicas aviárias. In: BICHARD, S. J.; SHERDING, R. G. Manual saunders: clínica de pequenos animais. São Paulo: Roca, 1998. cap. 1, p. 1397-1402.

6 DANI, S. U. A ema (Rhea americana): biologia, manejo e conservação. Belo Horizote, MG: Fundação Acangaú, 1993. $136 \mathrm{p}$.

7 HUCHZERMEYER, F. W. Doenças de avestruz e outras ratitas. Jaboticalal: FUNEP, 2000. 392 p.

8 SANTOS, A. A. Aspectos morfo-citoquímicos das células sanguíneas e ultra-estruturais de trombócitos e granulócitos de Gavião carijó Buteo magnirostris (GMELIN, 1877) (AVE FALCONIFORME), 2001. $97 \mathrm{f}$. Tese (Mestrado) - Escola Paulista de Medicina, Universidade Federal de São Paulo, São Paulo, 2001.
9 GREEN, R. A.; BLUE-MACLENDON, A. Ratite hematology. In: FELDMAN, B. F.; ZINKL, J. G.; JAIN, N. C. Scalm's veterinary hematology. 5th. ed. Baltimore: Lippincott Willians \& Wilkins, 2000. cap. 187, p. 12011206.

10 BANKS, W. J. Sangue. In: BANKS, W. J. Histologia veterinária aplicada. 2. ed. São Paulo: Manole, 1991. cap.11, p. 187-203.

11 BENEZ, S. M. Aves: criação, clínica, teoria, prática. Silvestres, ornamentais, avinhados. 3. ed. São Paulo: Robe, 2001. 522 p.

12 GENESER, F. Sangue. In: Histologia: com bases biomoleculares. 3. ed. Rio de Janeiro: Guanabara Koogan, 2003. cap. 10, p. 186-203.

13 SILVA, J. B. G. Rheacultura criação de emas: manual prático nutrição, reprodução, manejo e enfermidades. Guaíba: Agropecuária, 2001. 144 p.

14 RUPLEY, A. E. Patologia clínica. In: RUPLEY, A. E. Manual de clínica aviária. São Paulo: Roca, 1999. cap. 12, p. 369-430.

15 MAXWELL, M. H.; ROBERTSON, G. W. The avian basophilic leucocyte: a review. World's Poultry Science Journal, v. 51, p. 307-325, 1995.

16 MAXWELL, M. H.; ROBERTSON, G. W. The avian heterophil leucocyte: a review. World's Poultry Science Journal, v. 54, p. 155-178, 1998.

17 JUNQUEIRA, L. C.; CARNEIRO, J. Células do sangue. In: JUNQUEIRA, L. C.; CARNEIRO, J. Histologia básica. 10. ed. Rio de Janeiro: Guanabara Koogan, 2004. cap. 12, p. 224-237. 